\title{
An important spice, Pimenta dioica (Linn.) Merill: A Review
}

\author{
*Priya S Rao ${ }^{1}$, Sheth Navinchandra ${ }^{2}, \mathrm{KN}$ Jayaveera ${ }^{3}$ \\ ${ }^{1}$ Department of Pharmacognosy, C. U Shah College of Pharmacy E Research, Wadhwan, Gujarat, India \\ ${ }^{2}$ Department of Pharmaceutical Sciences, Saurashtra University, Rajkot, Gujarat, India \\ ${ }^{3}$ Department of Chemistry, JNTU, Anantapur, Andhra Pradesh, India
}

\begin{abstract}
Pimenta dioica (Linn.) Merill. Family: Myrtaceae, well known for its berries called Pimento, has been used as an important spice since time immemorial, for its culinary as well as medicinal qualities. It is also known as Allspice due to its intricate aroma which is a medley of aroma from spices such as Clove, Nutmeg and Cinnamon. In India, the leaves of Pimenta are used to flavor rice which gives it a typical aroma. Traditional culinary practice uses the dried berries for marinating meat. Various compounds have been isolated from the plant which belong to categories like phenylpropanoids, tannins, glycosides and essential oil. The present article is a humble effort to study the work done till date on this important spice.
\end{abstract}

Key Words: Allspice, Myrtaceae, Eugenol, Essential oil, Pimento, Jamaican pepper tree.

\section{INTRODUCTION}

\section{Plant Description}

Common or Other Local, Multi-lingual Names

Allspice, Jamaica Pepper, Pimento, Malagueta, Piment Jamaique, Pimenta, Pimienta Gorda, Dulce, English Spice, Tabasca, Toda Especial, Toute Epice (Seidemann, 2005).

\section{Synonym}

Synonyms for Pimenta dioica (L.) Merrill are Eugenia pimenta DC.; Myrtus dioica L.; Myrtus pimenta L.; Pimenta officinalis Lindley, Allspice tree, Jamaican pepper tree, Pimento tree (Riffle, 1998; Weiss, 2002).

\section{Botanical Description}

Botanical name of allspice is Pimenta dioica (L.) Merr. and it belongs to Myrtaceae family. It possesses an aromatic taste and flavor resembling a mixture of cinnamon, cloves and nutmeg, hence the name allspice (Neal, 1965; Weiss, 2002). Allspice is a small evergreen tree up to 15 meter tall with a pale brown bark. Leaves are simple, opposite, entire, oblong elliptical, 6-20 cm long, punctuate with pellucid glands which give off the odour of all-spice when crushed. The flowers are small and whitish with a peculiar aroma. They are present in groups of cymes. They are structurally hermaphrodite, but functionally dioecious. Those trees which bear no fruit are male trees wherein the flowers will have above 100 stamens and the flowers in bearing female trees have around 50 stamens. The receptacle has four cream-coloured calyx lobes, spreading at anthesis and persistent in the fruit. Petals are four, whitish and quickly deciduous. The style is white with a yellow stigma. In females, the style is slightly shorter and the stigma long than in the barren trees. The ovary is inferior and 2-celled, usually with I ovule in each cell. Plants flower during March-June and the fruit, which is a berry, matures 3-4 months later. For spice purpose, it is picked when it is fully developed, but still green. The fruits have two kidney-shaped seeds (Weiss, 2002; Parthasarathy, 2007).

\section{Botanical classification \\ Kingdom: Plantae-Plants \\ Subkingdom: Tracheobionta-Vascular plants \\ Superdivision: Spermatophyta-Seed plants \\ Division: Magnoliophyta-Flowering plants}




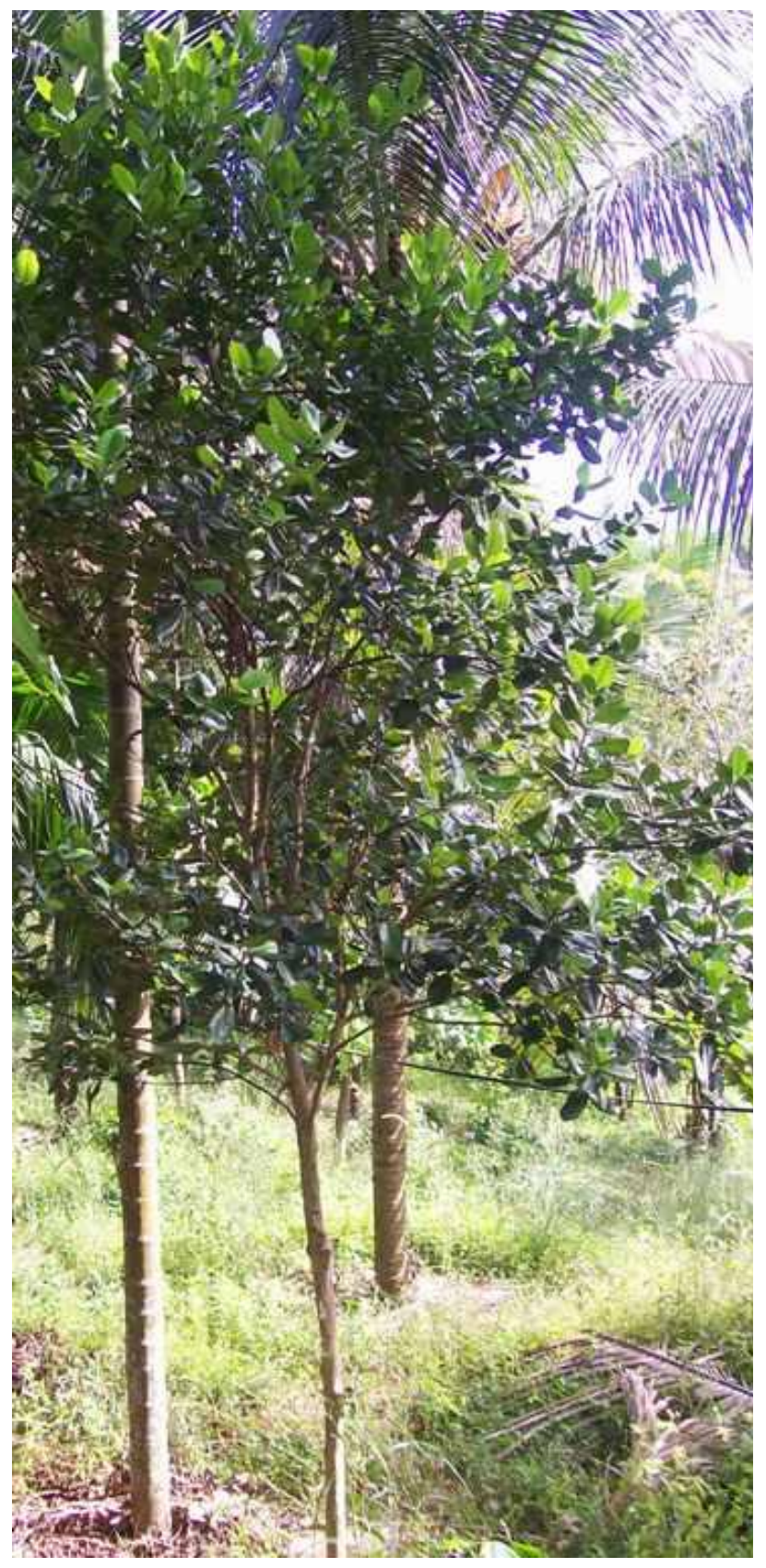

Figure 1: Allspice Tree.

Class: Magnoliopsida-Dicotyledons

Subclass: Rosidae

Order: Myrtales

Family: Myrtaceae - Myrtle family

Genus: Pimenta Lindl. - Pimenta

Species: Pimenta dioica (L.) Merr.

\section{Distribution/Ecology}

Pimenta dioica is native to the Caribbean region, especially Jamaica and Cuba; and trees grow naturally at a mean average temperature of $18^{\circ} \mathrm{C}$ -

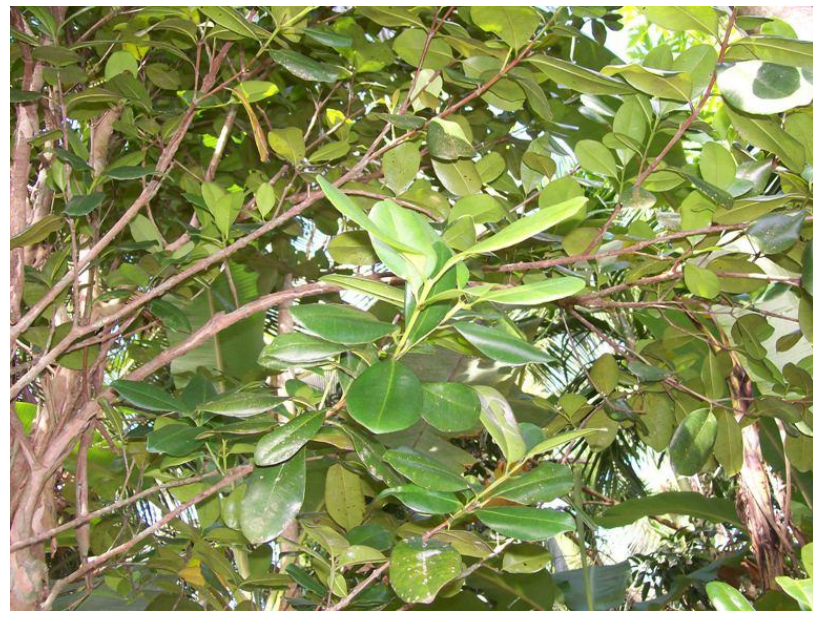

Figure 2: Pimenta Leaf.

$24^{\circ} \mathrm{C}$. Pimento is a forest tree and its seedlings benefit from shading until established. Like clove, pimento may require quite specific environmental conditions to flourish. Pimenta dioica is widely planted in warm regions of the world as an ornamental plant valued for its fragrance and attractive habit (Weiss, 2002).

\section{PARTS USED/KEY USES}

The dried, green-mature fruit is the commercial flavourant and curing agent. Its extract is an essential component in the classic liqueurs Chartreuse and Benedictine, and in the local Jamaican drink Pimento Dram. Ground fruits are preferred in desserts, relishes, sausages and preserves. Traditionally, a water extract of the berries is used to treat flatulence and diarrhea while the powdered fruit is used for corns, neuralgia and rheumatism. Young woody shoots of pimento are popularly made into walking sticks and umbrella handles. In India, it is used as an aromatic stimulant in digestive troubles, as an adjuvant to tonics and purgatives, as an anodyne against rheumatism and neuralgia (Anonymous, 1969). In Turkey, it is used as an aphrodisiac when taken along with honey (Sekeroglu et al., 2006). The essential oils of $P$. dioica leaves and fruits are utilized in food industry mainly meat and tanning industries as well as in perfumery compositions and cosmetic products. An oleoresin from the pimento berries is also produced in small quantities. The therapeutic properties of the essential allspice oils are anesthetic, analgesic, antimicrobial, antioxidant, antiseptic, acaricidal, 
Table 1: Names of the phytoconstituents found in different parts of the plant.

\begin{tabular}{|c|c|c|}
\hline Source & Name of The Phytoconstituent & Reference \\
\hline Berries & $\begin{array}{l}\text { Phenylpropanoids } \\
\text { threo-3-chloro-1-(4-hydroxy-3-methoxyphenyl)propane-1,2-diol } \\
\text { 3-(4-hydroxy-3-methoxyphenyl)propane-1,2-diol }\end{array}$ & Kikuizaki et al., 1999 \\
\hline \multirow[t]{2}{*}{ Berries } & $\begin{array}{l}\text { Glycosides } \\
\text { (4 S)- } \alpha \text {-terpineol 8-O- } \beta \text {-D-(6-O-galloyl) glucopyranoside } \\
\text { (4 R)- } \alpha \text {-terpineol 8-O- } \beta \text {-D-(6-O-galloyl) glucopyranoside } \\
\text { 3-(4-hydroxy-3-methoxyphenyl)propane-1,2-diol 2-O- } \beta \text {-D-(6-O-galloyl) } \\
\text { glucopyranoside }\end{array}$ & Kikuizaki et al., 2000 \\
\hline & $\begin{array}{l}\text { (2-hydroxy-3-methoxy-5-allyl)phenyl } \beta \text {-D-(6-O-E- } \\
\text { sinapoyl)glucopyranoside } \\
\left(1^{\prime} \mathrm{R}, 5^{\prime} \mathrm{R}\right)-5-(5 \text {-carboxymethyl-2-oxocyclopentyl)-3Z-pentenyl } \beta \text {-D-(6-O- } \\
\text { galloyl)glucopyranoside } \\
\text { (S)-R-terpinyl [R-L-(2-Ogalloyl) arabinofuranosyl]-(1f6)- } \beta \text {-D- } \\
\text { glucopyranoside } \\
\text { (R)-R-terpinyl [R-L-(2-O-galloyl)arabinofuranosyl]-(1f6)- } \beta \text {-D- } \\
\text { glucopyranoside }\end{array}$ & Kikuizaki et al., 2008 \\
\hline Leaf & $\begin{array}{l}\text { 6-hydroxy-eugenol 4-O-(6'-O-galloyl)- } \beta \text {-D-C1-glucopyranoside } \\
\text { 3-(4-hydroxy-3-methoxyphenyl)-propane-1,2-diol-2-O-(2',6'-di-O- } \\
\text { galloyl)- } \beta \text {-D-C1-glucopyranoside }\end{array}$ & Marzouk et al., 2007 \\
\hline Berries & $\begin{array}{l}\text { Tannins } \\
\text { Vascalaginone } \\
\text { Grandininol }\end{array}$ & Marzouk et al., 2007 \\
\hline Berries & $\begin{array}{l}\text { Essential Oil Constituents } \\
\text { limonene } \\
1,8 \text { cineole } \\
\text { terpinolene } \\
\beta \text {-caryophyllene } \\
\beta \text {-selinene } \\
\text { methyl eugenol }\end{array}$ & Tucker et al., 1991 \\
\hline Leaf & $\begin{array}{l}\text { Eugenol } \\
\text { Methyl Eugenol } \\
\beta \text {-caryophyllene } \\
\text { Myrcene }\end{array}$ & Jirovetz et al., 2007 \\
\hline
\end{tabular}

carminative, muscle relaxant, rubefacient, stimulant and tonic. Pimento oil can be helpful for the digestive system, for cramp, flatulence, indigestion and nausea. Further, the essential oils can help in cases of depression, nervous exhaustion, tension, neuralgia and stress and is used as natural repellent. The essential $P$. dioica leaf and fruit oil is also used in perfumes, aftershaves and commercial food flavoring (Sharma, 2003; Seidemann, 2005). Pimenta seed is reported to be used by Haitaian immigrants and their descendants in the province of Camaguey, Cuba to treat abdominal pain when taken triturated and ingested with rum and sugar (Volpato et al., 2009).

\section{HISTORY}

Pimenta dioica, commonly known as Allspice was used by early Central American civilizations as a flavoring for chocolate. The Spanish explorers of the 17th century gave Allspice the name Pimienta, because of its peppery flavor. As a medicine, Allspice has much the same use, as Cloves and their oils are similar. It works well as a digestive and has an antiseptic and slightly anaesthetic action (Ridley, 1983).

\section{CHEMICAL CONSTITUENTS}

Chemical substances found in different parts of the plant are listed in the table 1. 


\section{PHARMACOGNOSTICAL STUDY}

The pharmacognostical study of Pimenta leaf has been reported as a dorsiventral leaf with schizogenous and lysigenous oil glands (Rao et al., 2010).

\section{USES AND PHARMACOLOGY}

\section{Anticancer Activity}

A glucoside, extracted from Allspice has been used as an active ingredient of carcinogen-promoter inhibitors. The glucoside at $100 \mu \mathrm{g}$ is reported to inhibit $100 \%$ Epstein-Barr virus early antigen formation. Pedunculagin was found to be most cytotoxic compound against solid tumour cancer cells and inhibited proliferation of T-lymphocytes and macrophages. Pimenta dioica was used as an ingredient in Tibetan remedy PADMA 28 and was found to induce apoptosis in $\mathrm{T}$ cell derived lymphocytic leukemia cell line CEM-C7H2 (Jenny et al., 2005).

\section{Antifungal Activity}

Pimenta dioica berry oil was found to completely inhibhit Fusarium oxysporum, F. verticilloides, penicillium brevicompactum, P. expansum, Aspergillus flavus and A.fumigatus at $1 \mu \mathrm{l} / \mathrm{ml}$ concentration. Antifungal activity was also shown by the essential oil of allspice berries against Aspergillus niger, Candida blanki, Candida tropicalis, Candida cylindracea, Saccharomyces cerevisiae and Candida albicans. It showed moderate inhibitory activity against Candida glabrata, Candida krusei, Candida albicans (Oussalahet al., 2007, Oussalah et al., 2006 and Kamble et al., 2008).

\section{Antimicrobial Activity}

Pimenta dioica extract was found to inhibit $S$. aureus and P. aeruginosa (Marzouk et al., 2007). The essential oil of Pimenta dioica berries was found to inhibit Pseudomonas putida, E.coli, Listeria monocytogenes, Salmonella typhimurium and Staphylococcus aureus (Oussalah et al., 2006). The essential oil of Pimenta dioica leaves showed a strong antibacterial activity against Coagulase negative Staphylococci and Pseudomonas species and a strong antifungal activity against Aspergillus niger (Rao et al., 2001).

\section{Nematicidal Activity}

Allspice berry oil showed good nematicidal activity at $2 \mathrm{mg} / \mathrm{ml}$ against the pinewood nematode, Burasaphelenchus xylophilus (Park et al., 2007).

\section{Antioxidant Activity}

The dichloromethane extract, ethyl acetate soluble fraction and water soluble fraction of allspice berries showed effective antioxidant activity by the ferric thiocyanate method and oil stability index method. It also showed good free radical scavenging activity by the DPPH method (Kikiuzaki et al., 2000).

A phenylpropanoid, threo-3-chloro-1-(4-hydroxy-3methoxyphenyl)propane-1,2-diol, has been isolated from the berries of Pimenta dioica together with five known compounds, eugenol, 4-hydroxy-3-methoxycinnamaldehyde, 3,4-dimethoxycinnamaldehyde, vanillin and 3-(4-hydroxy-3-methoxypheny) propane-1,2-diol was found to show inhibition of autooxidation of linoleic acid in a water alcohol system (Kikiuzaki et al., 1999). Aqueous extract of Pimenta berries showed 91.7\% DMPO scavenging when determined by ESR spectra (Young et al., 2002).

Pimento leaf oil from Jamaica showed good free radical scavenging activity in case of hydroxyl radical ( $\mathrm{IC}_{50}$ value was determined to be $0.29 \mu \mathrm{g} / \mathrm{ml}$ ) when compared to DPPH ( $\mathrm{IC}_{50}$ value was determined to be $1.79 \mu \mathrm{g} / \mathrm{ml}$ ). Xanthine oxidase activity was found to be inhibited upto $74.83 \%$. Superoxide scavenging was found to be $95.93 \%$. It also showed antioxidant activity in a linoleic acid emulsion model system, at a concentration of $0.005 \%$ the sample inhibited conjugated diene formation by $65.47 \%$ and generation of secondary linoleic acid oxidation products by $72.98 \%$ (Jirovetz et al., 2007).

\section{Antidiabetic Effect}

Ground Jamaican Pimento berries have been reported to inhibit protein glycation indicating its potential to be used as an effective antidiabetic agent (Dearlove et al., 2008).

\section{REFERENCES}

Anonymous. (1969). Wealth of India (Raw Materials). Volume 8, Pages 58-59, Publications Informations Division, CSIR Publications. New Delhi,

H. Ridley. (1983). Spices. London: Published by Mac Milan and Company Ltd. Pages 197-199.

Haitaian immigrants and their descendants in the province of Camaguey, Cuba. Journal of Ethnobiology and Ethnomedicine. Issue 5, Page 16. [DOI] 
Jenny, M., Schwaiger, W., Bernhard, D., Wrulich, O., Cosaceanu, D., Fuchs, D and Ueberall, F. (2005). Apoptosis induced by the Tibetan herbal remedy PADMA 28 in the T cell-derived lymphocytic leukaemia cell line CEM-C7H2. Journal of Carcinogenesis. Volume 4, Page 15. [DOI]

Jirovetz, L., Buchbauer, G., Stoilova, I., Krastanov, A., Stoyanova, A and Schimdt, E. (2007). Spice Plants: Chemical composition and antioxidant properties of Pimenta Lindl. Essential oils, Part 1: Pimenta dioica (L.) Merr., leaf oil from Jamaica. ErNährung/Nutrition. Issue 2, Pages 5562.

Kamble Vilas, A and Patil S.D. (2008). Spice derived essential oils: Effective antifungal and possible therapeutic agents. Journal of herbs, spices and medicinal plants. Volume 14, Issue 3, Pages 129-143. [DOI]

Kikiuzaki, H., Hara, S., Kawai, Y and Nakatani, N. (1999). Antioxidative phenylpropanoids from berries of Pimenta dioica. Phytochemistry. Issue 52, Pages 1307-1312. [DOI]

Kikiuzaki, H., Miyajima, Y and Nakatani, N. (2008). Phenolic glycosides from Berries of Pimenta dioica. J. Natural Products. Issue 71, Pages 861-865. [DOI]

Kikiuzaki, H., Sato, A., Mayahara, Y and Nakatani, N. (2000). Galloylglucosides from Berries of Pimenta dioica. Journal of Natural Products. Issue 63, Pages 749-752. [DOI]

Mohamed, S., Marzouk, A., Fatma, A., Moharram, Mona, A., Mohamed, Amira M., Gamal-Eldeen, and Elsayed A, A. (2007). Anticancer and Antioxidant Tannins from Pimenta dioica Leaves. Z. Naturforsch. Issue 62(c), Pages 526-536. PMID: 17913067.

Neal, M. C. In Gardens of Hawai'i. Bernice P. (1965). Bishop museum special publication 40, Bishop Museum Press, Honolulu, HI.

Oussalah, M, Caillet, S, Lacroix, L. S. M. (2007). Inhibitory effects of selected plant essential oils on the growth of four pathogenic bacteria: E coli 0157: H7, Salmonella typhimurium, Staphylococcus aureus and Listeria monocytogenes. Food control. Issue 18, Pages 414-420. [DOI]

Oussualah, M, Caillet, S, Saucier, L, Lacroix, M. (2006). Antimicrobial effects of selected plant essential oils on the growth of Pseudomonas putida strain isolated from meat. Meat Science. Issue 73, Pages 236-244. [DOI]

Park I.K., Kim J., Lee S.G., Shin, S, C. (2007). Nematicidal Activity of Plant Essential Oils and Components From Ajowan (Trachyspermum ammi), Allspice (Pimenta dioica) and Litsea (Litsea cubeba) Essential Oils Against Pine Wood Nematode (Bursaphelenchus Xylophilus). J Nematol. Volume 39, Issue 3, Pages 275-279. PMID: 19259498

Parthasarathy, V.A, Kandiannan, K. (2007). Spices and condiments. Indian institute of spices research, Calicut.

Rao S. K., Iyengar, M. A and Rao, G. (2001). Anti-microbial activity of the essential oil of the leaves of Pimenta dioica, Linn (Family: Myrtaceae), Indian Drugs. Volume 38, Issue 9, Pages $458-461$.

Rao, P. S., Sheth, N. R., Jayaveera, K, N and Rao, S. K. (2010). Pharmacognostic standardisation of the leaves of Pimenta dioica linn, International Journal of Pharmaceutical Sciences and Research, Volume 1, Issue 9, Pages 110-115.

Rebecca, D, Greenspan, P., Hartle, D., Swanson, B, R and Hargrove, J. L. (2008). Inhibition of protein glycation by extracts of Culinary herbs and spices. Journal of medicinal food. Volume 11, Issue 2, Pages 275-281. [DOI]

Riffle, R.L. (1998).The Tropical look. Timber press. Portland.

Seidemann J. (2005). PIMENTA Lindl.-Allspice-Myrtaceae. World Spice Plants, Springer-Verlag, Heidelberg. Pages 286-287.

Sekeroglu, N., Kaya A. D., Inan, M and Kirpik, M. (2006). Essential oil components and ethanopharmacological characteristics of some spices and herbal drugs traded in Turkey. International Journal of Pharmacology. Volume 2, Issue 2, Pages 256-261. [DOI]

Sharma R. (2003). Pimenta. Medicinal plants of India -An encyclopedia. Data Publishing House Delhi, New Delhi.

Tucker, A. O and Maciarello, M. J. (1991). Volatile Leaf Oils of Caribbean Myrtaceae. II. Pimenta dioica [L.] Merr. of Jamaica. J. Essential Oil Research, Volume 3, Page 195. [DOI]

Volpato, G., Godinez, D., Beyra, A., and Barreto, A. (2009) Uses of medicinal plants by

Weiss, E. A. (2002). Spice Crops. CABI Publishing, New York.

Yun, Y. S., Nakajima, Y., Iseda, E and Kunugi, A. (2002). Determination of antioxidant activity of herbs by ESR. Journal of Food hygiene Society, Japan. Volume 44, Issue 1, Pages 59-62. [DOI] 